\title{
Biolistic-Mediated Transient Gene Expression in Shoot Apical Meristems of the Prickly-Pear (Opuntia ficus-indica)
}

\author{
Romulo Marino Llamoca-Zárate ${ }_{1,2}^{1,}$ Luiz Ferreira Aguiar Ponte ${ }^{1}$, Joerg Landsmann ${ }^{2}$ and \\ Francisco de Assis Paiva Campos ${ }^{1 *}$ \\ IDepartment of Biochemistry and Molecular Biology, Federal University of Ceará, P.O. Box 1065, 60001-970 \\ Fortaleza, Ceará, Brazil and ${ }^{2}$ Institute for Plant Virology, Microbiology and Biosafety, Federal Biological \\ Research Centre for Agriculture and Forestry, Messeweg 11/12, D-38104 Braunschweig, Germany.
}

\begin{abstract}
We have demonstrated the transient expression of the GUS gene in cells of the meristematic apical dome of Opuntia ficus-indica. DNA delivery into the cells was achieved using a biolistic PDS-1000He instrument from Bio-Rad Laboratories. The transforming DNA was coated in tungsten particles with diameter of $1.3 \mu \mathrm{m}$ and the distance between the flying disk and the target tissue was $7.5 \mathrm{~cm}$ and the shooting pressure was adjusted to 1200 psi. This is the first demonstration that the biolistic transformation system can be used to express a transgene in a member of the Cactaceae.
\end{abstract}

Key words: Opuntia ficus-indica, prickly-pear, Cactaceae, transient gene expression, particle bombardment.

\section{INTRODUCTION}

The prickly-pear (Opuntia ficus-indica) is a cactus widely utilised in semi-arid regions as a forage crop. Its usefullness is highlighted in years of drought, where in many occasions its fleshy phylloclads are the sole source of water and nutrient for farm animals (Russel \& Felker, 1987). In our laboratory we are interested in exploring the possibilities of using new biotechnological tools to improve the quantitative and qualitative protein profile in phylloclads in order to increase its nutritional value. To this end we are studying patterns of protein synthesis and deposition in phylloclads and seeds (Uchoa et al., 1998) and developing technologies for plant transformation, regeneration and for the mass propagation of elite clones (Zarate \& Campos, 1995). Here we present data showing the expression of a reporter gene in shoot apical meristems, following particle bombardment. The biolistic method, which bypasses the problems associated with Agrobacterium host range, offers an alternative approach for the delivery of DNA into plant cells. It has been used in transient and/or integrative transformation of many plants, such as rice (Jain et al., 1996), cassava (Schopke et al., 1996), sugarbeet (Mahn et al., 1995) and black spruce (Charest et al., 1996). This is the first demonstration that this technique can be used to express a transgene in a member of the Cactaceae.

\section{MATERIAL AND METHODS}

Plant materials and culture conditions Mature cladodes were collected in Tauá, Ceará and propagated in the greenhouse (Santos et al., 1997). Greenhouse plants were used as source of young cladodes, which in turn were used for mass propagation by axillary proliferation (Zarate \& Campos, 1995). Shoot apical meristems $\quad(0.5-0.8 \mathrm{~mm})$ were excised

\footnotetext{
* Author for correspondence
} 
asseptically from young shoots and cultured in MS medium supplemented with 5\% sucrose, $0.5 \mathrm{mg} / \mathrm{l}$ benzyl adenine, $0.1 \mathrm{mg} / \mathrm{l}$ giberelic acid and solidified with $0.8 \%$ agar. They were kept in this medium for 12-16 hours before bombardment.

Transforming DNA - The plasmids used were: (1) pFF19G (Timmermans et al., 1990), which contains the uidA gene controlled by the CaMV35S promoter; (2) pNG (Mahn et al., 1995) which contains the uidA and $n p t I I$ genes both under the control of the CaMV35S promoter and (3) pPARGUSH (Landsmann et al., 1988), which contains the nptII gene under the control of the nos promoter and the uid A gene under the control of the par promoter. The DNA coated particles were prepared as previsously described (Sanford et al. 1993) with modifications (Mahn, 1996).

Particle bombardment - We used a Biolistic PDS-1000He instrument from Bio-Rad Laboratories, and the conditions for bombardment were those described (Sauter et al. 1991). The tungsten particles in which the transforming DNA was coated had a diameter of $1.3 \mu \mathrm{m}$, the distance between the flying disk and the target tissue was $7.5 \mathrm{~cm}$ and the shooting pressure was adjusted to 1200 psi. As positive controls, tobacco leaves were bombarded with the same constructs. Shoot apical meristems of the prickly-pear were also bombarded with uncoated particles, in order to test the presence of endogenous GUS activity.

\section{Determination of Transient Expression} Following Bombardment - The histochemical determination of GUS activity (Jefferson, 1987) was performed 48-72 hours after bombardment. The meristems were transferred to a sterile solution containing $50 \mathrm{mM} \mathrm{K}_{3}[\mathrm{Fe}(\mathrm{CN}) 6], 50 \mathrm{mM}$ $\mathrm{K} 4\left[\mathrm{Fe}(\mathrm{CN})_{6}\right], 0.1 \mathrm{M} \mathrm{Na} 2 \mathrm{HPO} 4,0.3 \%$ X-GLUC and $0.1 \%$ Triton $\mathrm{X}-100$. After 24 hours of incubation at $37{ }^{\circ} \mathrm{C}$ in the dark, the meristems were fixed in $70 \%$ ethanol and observed under a binocular microscope. Blue coloured meristems indicated expression of the uidA gene in the respective plant cells.

\section{RESULTS AND DISCUSSION}

Our preliminary experiments (data not shown) to determine the best particle diameter and shooting pressure indicated that particles with $1.3 \mu \mathrm{m}$ of diameter and a shooting pressure of 1200 psi always yielded good results and therefore was used in all of our experiments. The results of the transient expression experiments indicated successful delivery of foreign DNA into apical meristem cells of the prickly-pear (Figure 1, Table I). Cells of the central zone of the meristem transiently expressed the GUS gene; meristem cells expressed the reporter gene at a higher frequency than surrounding tissues (Figure 1C). Control meristems bombarded with uncoated particles did not show any blue spots (Figure 1B) thus demonstrating the lack of endogenous GUS activity in $O$. ficus-indica tissues. We could not detect any difference in frequency of expression of the transgene when the meristems were bombarded with plasmids pNG, pFF19G and pARGUSH (Table I).

This is the first report on the expression of a transgene in the Cactaceae. Mastering transformation in O. ficus-indica would open new prospects for improving this species of great economic importance for small farmers in the Brazilian north-east. Transient gene expression has become a valuable tool to evaluate conditions for optimal gene transfer and to study the regulation of gene expression (Potrykus \& Spangenberg, 1995). We are currently using the transformation protocol shown here in order to achieve integrative transformation in callus and cell suspension cultures of the prickly-pear. 

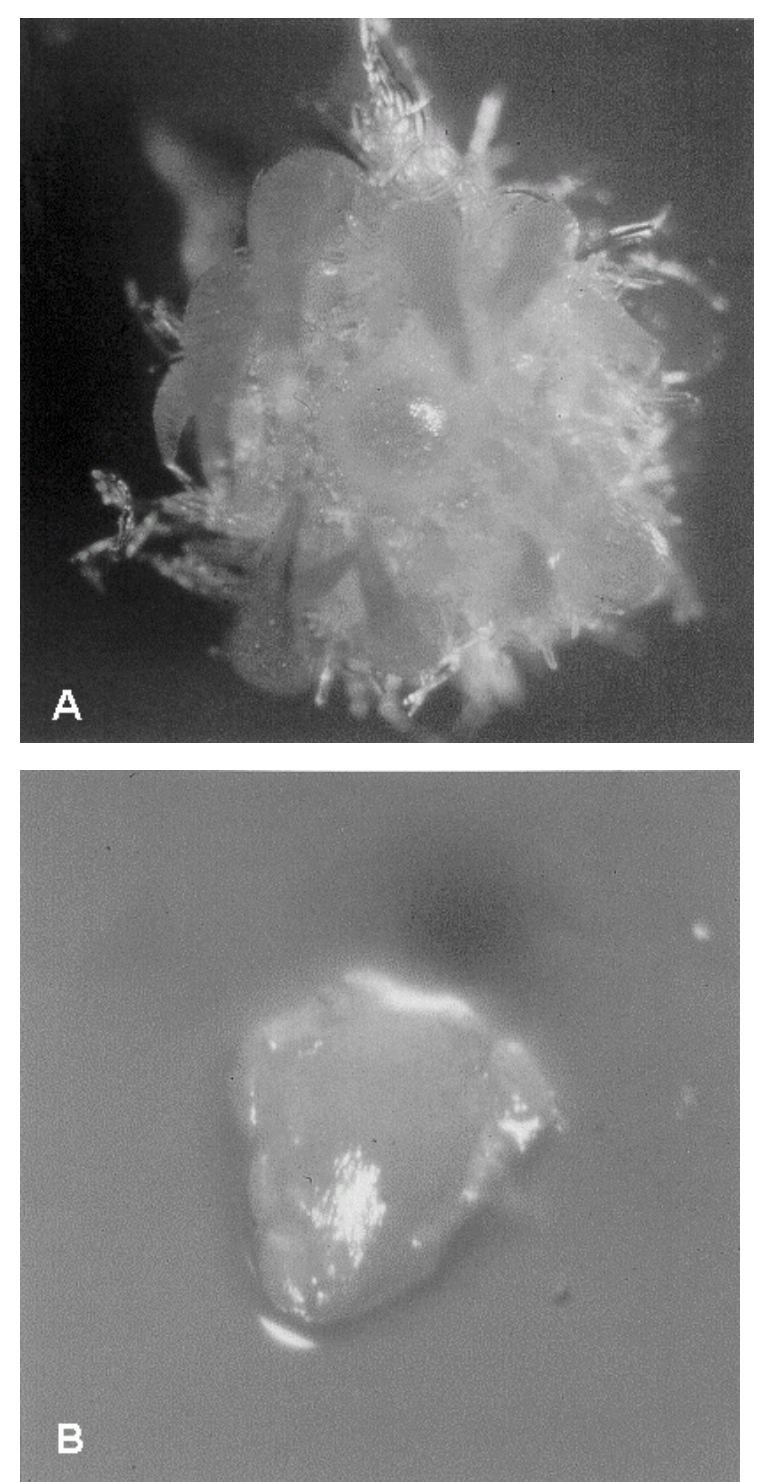

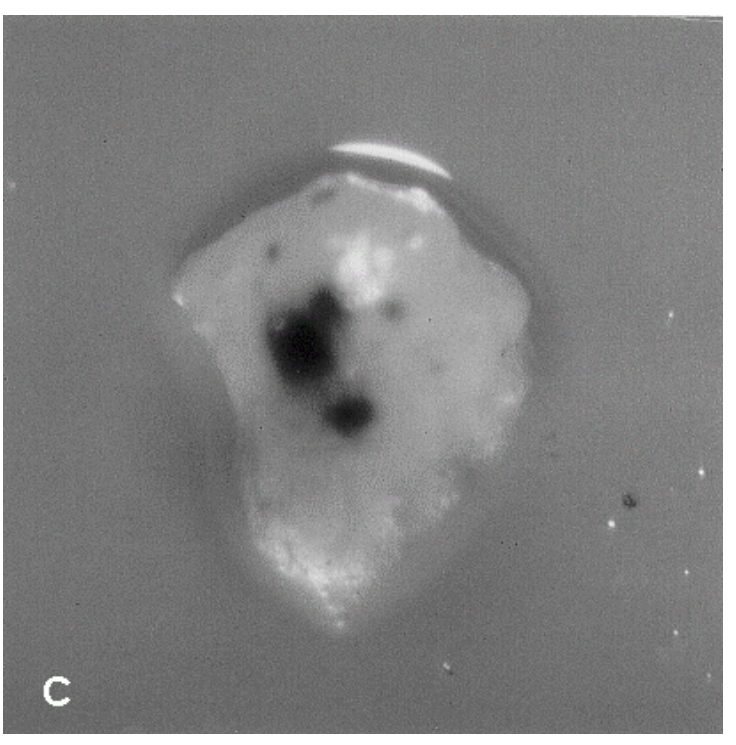

Figure 1: Transient expression of the GUS gene in apical meristem cells of prickly-pear (bars represent $0.5 \mathrm{~mm}$ ). (A) Seven days old shoot apex; (B) Apical meristem isolated from seven days shoots; (C) Apical meristem isolated from seven days old shoots, after particle bombardment (plasmid pFF19G).

Table I: Percentage of transient expression of the GUS gene in isolated apical meristems of $O$. ficus-indica after particle bombardment. All experiments were repeated three times, with the same number of meristems/experiment.

\begin{tabular}{l|c|c}
\hline Plasmid & Number of bombarded meristems & Percentage of transient expression $\left(^{*}\right)$ \\
\hline pFF19G & 90 & $34.7 \pm 1.2$ \\
pNG & 90 & $36.6 \pm 1.3$ \\
pPARGUSH & 90 & $34.4 \pm 1.7$ \\
\hline
\end{tabular}

(*) Data were subjected to analysis of variance and the percentage of transient expression achieved by using plasmids pFF19G, pNG and pPARGUSH did not differ statistically at $1 \%$ level by F test.

\section{ACKNOWLEDGEMENTS}

We would like to thank Ms. Gerhild Juettner for her help with the particle gun. This work was financed by the Brazilian National Research
Council (CNPq), the Brazilian Ministry of Education through the Coordenação de Pessoal de Nível Superior (CAPES) and the Deutscher Akademischer Austauschdienst (DAAD). 


\section{RESUMO}

Nós demonstramos a expressão transiente do gene GUS nas células do meristema apical de Opuntia ficus-indica. A introdução do DNA nas células foi realizada através de um sistema de biolística PDS-1000He da Bio-Rad Laboratories. Para transformação, partículas de tungstenio com diâmetro de $1,3 \mu \mathrm{m}$ foram cobertas com DNA e a distância entre o disco das partículas e o tecido alvo foi de 7,5cm, a pressão de tiro foi 1200 psi. Esta é a primeira demonstração que o sistema de biolística de transformação pode ser usado para a expressão de transgenes nas cactáceas.

\section{REFERENCES}

Charest, P. J., Devantier, Y. \& Lachance, D. (1996), Stable genetic transformation of Picea mariana (black spruce) via particle bombardment. In Vitro Cell Dev. Biol., 32, 91-99

Jain, R. K. (1996), Optimization of biolistic method for transient gene expression and production of agronomically useful transgenic Basmati rice plants. Plant Cell Rep., 15, 963-968

Jefferson, R. A. (1987), Assaying chimaeric genes in plants: the GUS gene fusion system. Plant Mol. Biol. Rep., 5, 387-405

Landsmann, J., Llewelyn, D., Dennis, E. S. \& Peacock, W. (1988), Organ regulated expression of the Parasponia andersonii haemoglobin gene in transgenic tobacco plants. Mol. Gen. Gen., 214, 68-73

Mahn, A. (1996), Untersuchungen zur Nutzung des direkten Gentransfers fuer die transformation von Zuckerruebe (Beta vulgaris). $\mathrm{PhD}$ Thesis, Technische Universitat Braunschweig, Germany.

Mahn, A., Matzk, A., Sautter, C. \& Schiemann, J. (1995), Transient gene expression in shoot apical meristems of sugarbeet seedlings after particle bombardment. J. Exp. Bot., 46, 1625-1628

Potrykus, I. \& Spangenberg, G. (1995). Gene Transfer to Plants. Springer-Verlag, Berlin, $362 p$
Russel, C. E. \& Felker, O. (1987), The Prickly-Pears (Opuntia spp., Cactaceae): A source of human and animal food in semiarid regions. Economic Bot., 41, 433445

Sanford, J.C., Smith, F.D. \& Russell, J.A. (1993), Optimizing the biolistic process for different biological applications. Meth. Enzimol., 217, 483-509

Santos, D. C., Farias, I., Lira, M., TavaresFilho, J., Santos, V. F. \& Arruda, G. P. (1997), A palma forrageira (Opuntia ficusindica Mill) em Pernambuco:cultivo e utilização. Recife:IPA, (IPA. Documentos, 25)

Sauter, C., Waldmer, H., Neuhaus-Uri, G., Galli, A., Neuhaus, G. \& Potrykus, I. (1991), Micro-targeting high efficiency gene transfer using a novel approach for the acceleration of microprojectiles. Bio/Technol., 9, 1080-1085.

Schopke, C., Taylor, N., Carcamo, R., Konan, N. K., Marmey, P., Henshaw, G. G., Beachy, R.N. \& Fauquet, C. (1996), Regeneration of transgenic cassava plants (Manihot esculenta Crantz) from microbombarded embryogenic suspension cultures. Nature Biotechnol., 14, 731-735

Timmermans, M.C.P., Maliga, P., Vieira, J. \& Messing, J. (1990), The pFF plasmids cassetes utilizing CaMV sequences for expression of foreign genes in plants. $J$. Biotechnol., 14, 333-344

Uchoa, A. F., Souza, P. A. S., Gomes-Filho, E. \& Campos, F. A. P. (1998), Isolation and characterisation of a reserve protein from the seeds of Opuntia ficus-indica (Cactaceae). Braz. J. Med. Biol. Res., 31, 757-761.

Zarate, R. M. L. \& Campos, F. A. P. (1995), Micropropagação da palma forrageira (Opuntia ficus-indica). In: Congresso Brasileiro de Botânica, Recife, PE, Resumos. p.79 